\title{
A HUMORSTÍLUS ÉS A KREATIVITÁS KÜLÖNBÖZŐ ASPEKTUSAINAK ÖSSZEFÜGGÉSEI
}

\author{
SÉRA LÁSZLÓ - BODA-UJLAKY JUDIT¹ - GYEBNÁR VIKTÓRIA \\ ${ }^{1}$ SE TSK Pszichológia Tanszék \\ E-mail: serlasz43@gmail.com; ujlaky@tf.hu; gyebria@gmail.com \\ Beérkezett: 2013. március 19. - Elfogadva: 2014. szeptember 9.
}

\begin{abstract}
A humorérzék, a humor megértési és produkciós képessége kreatív tulajdonság, jelentös egyéni különbségekkel, ám mind ez idáig nem egyértelmüen tisztázott a humorprodukció és a kreativitás viszonya. Vizsgálatunkban 133 fö különféle önbeszámolós és viselkedéses humorprodukciós, humorhasználatra vonatkozó, illetve kreativitástesztet töltött ki. Nemi különbségek sem a kreativitás-, sem a humortesztekben nem mutatkoztak. Eredményeink szerint meglehetösen gyenge, de pozitív összefüggés mutatkozik a humorprodukció és a kreativitás között, illetve a humorstílusok között, ami összességében a két folyamat közös alapjaira, ám azok eltérö jellegére mutat rá.
\end{abstract}

Kulcsszavak: humor, kreativitás, humorprodukció, humorstílus

\section{BEVEZETÉS}

A humor a gondolatokat mulatságossá, fantasztikussá tevő szellemi minőség; üzenet, amelynek szellemessége vagy nyelvi furfangja, vagy inkonguitása nevetést vált ki. Össze nem illésről vagy inkongruitásról akkor beszélünk, amikor a (humoros) inger a kognitív vonatkoztatási modelltól (a tudás elsajátítása során kialakított tudáskészlettől, sémától vagy forgatókönyvtől, fogalmi kerettől) különbözik. „A humort képletesen egy feldobott érmének írhatjuk le, amely olyan gyorsan pörög, hogy egyidejűleg mindkét oldalát láthatjuk" (WICKER, 1985). Ez a megközelítés a humor megértését és létrehozását a problémamegoldó gondolkodással és a belátás folyamatával összekapcsoló alaklélektani hagyományhoz, így (Harkai) Schiller Pál (SCHILLER, 1938) vagy Arthur KOESTLER (1964/1998) elképzeléseihez, és a belátás 
szerepének empirikus alátámasztását is nyújtó újabb kutatásokhoz (KOzBELT és NISHIOKA, 2010) illeszkedik.

KOESTLER (1964/1998) ezzel összefüggésben biszociatív folyamatról beszél: „A humor minden fajtájának szerkezeti alapmintázata biszociatív; egy helyzet vagy esemény egyidejűleg két, összeférhetetlen asszociatív összefüggésrendszerben való szemlélése, ami a gondolatfolyamatnak egyik mátrixból egy egész más logikai vagy játékszabály uralta másikra való hirtelen átugrását eredményezi” (KOESTLER, 1964/1998, 110).

Koestler összekapcsolja a művészi inspirációt, a tudományos felfedezést és a komikus találékonyságot: „Minden kreatív tevékenység [...] alapmintázata - a tudás már meglévő, de mindeddig elkülönült területeinek, fogalomköreinek vagy vonatkoztatási rendszereinek összerázása - azonos" (KOESTLER, 1967/2000, 255; vö. UŐ, 1964/1968, 1981). Munkája óta a humort tartják a kreatív folyamat legjobb illusztrációjának.

A humor és a kreativitás kapcsolatára valószínủleg Auguste Penjon, francia filozófus figyelt fel először, akinek híres állítása 1891-ből - „a nevetés semmi más, mint a szabadság kifejezése, amelyet átélünk, vagy amire vágyunk" - a szokásos racionális gondolkodástól való elszakadásra vagy „kognitív játékosságra” való utalásként értendő (ZIV, 1989, 105).

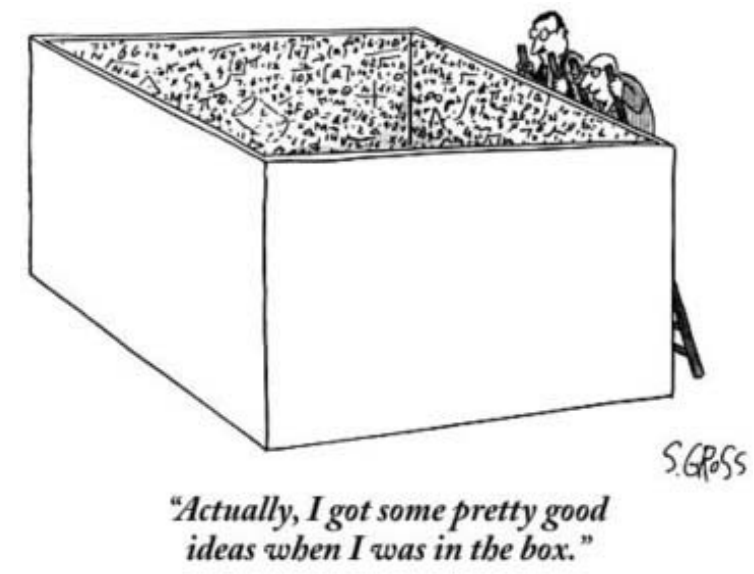

1. ábra. Sam GRoss, 2006. The New Yorker, Cartoon Bank, item \#8545464.

Sam Gross karikatúrája (1. ábra) jól illusztrálja ezt a kapcsolatot s Koestler felvetését. A képaláírás azt az angol kifejezést tartalmazza, mégpedig annak szó szerinti értelmével manipulálva (,thinking outside the boksz”, „thinking beyond the boksz"), amelynek jelentése: nem szokványos, új perspektívából való gondolkodás, vagy a kliséktől való eltérés. Az ábraszöveg: „Igazából, mindenféle jó elképzelésem támadt, amíg szokványosan gondolkodtam". 
A kreativitáson általában új és hasznos gondolatok, ötletek kitalálásának képességét értik bármely területen. Alkotóképesség, amely új, eredeti, nem elvárt, jó minőségű és használható, s a feladat követelményeinek megfelelő dolgokat eredményez (STERNBERG és LUBART, 1999), vagy egyszerűen „sikeres eredetiség” (O'QUiN és DERKs, 2011). Lehet személyesen újnak és jelentősnek értelmezni, jóllehet a hasznosságot tekintve: „Egy produktum vagy egy válasz olyan mértékben kreatív, amennyiben megfelelő független megfigyelők egyetértenek abban, hogy kreatív. Megfelelő megfigyelő az, aki ismeri a produktum területét..." (AMABILE, 1996, 33). Egy újabb, a kreativitást mint túlélési ráfordítást (szemben a szexuális ráfordítással) hangsúlyozó megközelítés meghatározása szerint a kreativitás tartalmazza a „korábban példa nélküli vagy új észlelés, gondolat, vagy cselekvés folyamatát és eredményét egyaránt, melynek segítségével egy élőlény vagy élőlények egy csoportja környezete összetételének és struktúrájának jelen vagy lehetséges változásaival megküzd" (GREENBERG, 2004, 310).

Az utóbbi évek egyik legkiterjedtebben vizsgált evolúciós feltételezése szerint, amely Geoffrey MiLLER (2000, 2006) nevéhez füződik, a szándékos humor szexuális szelekcióval alakult ki az evolúció során, s párválasztási eszközként működik mindkét nem számára. Az érvelés szerint az emberi mentális jellegek (intelligencia, kreativitás, művészi kifejezés, zenei képesség, humorérzék) szexuális szignál, a genetikus minőségek vagy a genetikai rátermettség („fitness”) jelzései. Így a humor és a kreativitás megjelenik a nemre jellemző párválasztási stratégiákban (leegyszerűsítve: a nő a választó nem, s ezért preferálja a humoros férfit) (lásd még DewitTe és Verguts, 2001; Bressler, Martin és BALSHine, 2006; GreENGross és Miller, 2011; Kaufman, Kozbelt, Bromley és Miller, 2008; Li, Griskevicius, Durante, Jonason, Pasisz és Aumer, 2009; Tisljár, 2011).

Elterjedt vélemény, hogy a hatékony humorprodukció úgy hat, mint az intelligencia nyilvánvaló jelzője; továbbá a humor és a játékosság a kreatív emberek megkülönböztető jellemzője. Vannak bizonyítékok arra vonatkozóan, hogy a jó humorérzék kreativitással (illetve intelligenciával) társul. Így KAUFMAN és KOZBELT (2009) rámutattak, hogy a hivatásos humoristák, vígjátékírók és komikusok kreatív és verbálisan intelligens emberek, s a komikusok hajlandók túllépni életük szerencsétlen fordulatain, a humort megküzdésre használva. Empirikus kutatásokban hivatásos komikusoknál $(\mathrm{N}=31)$ magasabb verbális intelligencia-pontszámot és jobb humorprodukciós teljesítményt állapítottak meg, mint az egyetemisták csoportjában (GreEngross, MARTin és MiLler, 2011). Egy másik vizsgálat kimutatta, hogy az ötletek előhívásának képessége jól korrelál a kreatív ötletekkel $(r=0,82)$; improvizációs komikusok 20\%-kal több termékötletet vetettek fel, mint a hivatásos terméktervezők (KUDROWITZ, 2010). A tehetséges gyerekek számára „a humor elemzése és magasabb szintű humor létrehozása különösen élvezetes és kreatív aktivitás" (BERGEN, 2009, 434); jobb a humorérzékük és a humort korábbi életkorban értik meg, mint a tipikusan fejlődő, 10-12 éves társaik, és jobban élnek a humor megküzdési eszközének lehetőségével (HOLT, 1996; HOLT és WILLARDHOLT, 1995). Egy másik vizsgálat szerint a humoros diákok produktívak, kreatívak és kedveltek (FABRIzI és POLLIO, 1987). Mind a humor, mind a kreativitás tekinthető problémamegoldásnak, s vizsgálható gyengén definiált, nem egyetlen 
megoldást tartalmazó problémákkal. Sokféle teszt alkalmazásával állapítottak meg pozitív kapcsolatot közöttük (Brodzinsky és RUBIEN, 1976; DERKs és Hervas, 1988; Fabrizi és Pollio, 1987; Feingold és Mazzella, 1993; Humke és SCHAFER, 1996; Murdock és Ganim, 1993; Treadwell, 1970; Ziv, 1976, 1989). A vizsgálatok némely eredményét lásd az 1.táblázatban. Összefoglalásukban O’QUIN és DERKs $(2011,632)$ úgy vélik, hogy „számos tanulmány korrelációja a humorprodukció és a változatos kreativitásmérések között hasonlóképpen mérsékelt nagyságúak, mint a humor egyéb mérései, például a humor élvezése és a humorérzék közötti korrelációk".

1. táblázat. A humorprodukció és a kreativitás közötti korrelációk néhány korábbi vizsgálatban (KUDROWITZ, 2010, 17, a szerző engedélyével)

\begin{tabular}{|c|c|c|c|}
\hline V i z s gála t & $\mathrm{Humorteszt}$ & Kreativitásteszt & Max. $r$ érték \\
\hline 1965 SMith és White & Ön- és társértékelés & Szóasszociáció & $+0,18 \quad p<0,5$ \\
\hline 1970 TREADWELL & $\begin{array}{l}\text { Karikatúrafelirat, } \\
\text { önbeszámoló }\end{array}$ & $\begin{array}{l}\text { Távoli asszociáció, } \\
\text { Gestalt-kiegészítés }\end{array}$ & $+0,275 p=0,05$ \\
\hline $1974 \mathrm{BABAD}$ & $\begin{array}{l}\text { Karikatúrafelirat, } \\
\text { humorélvezet, társ- } \\
\text { értékelés }\end{array}$ & $\begin{array}{l}\text { Torrance Körök } \\
\text { tesztje, mondat- } \\
\text { kiegészítés }\end{array}$ & $+0,08 \quad p<0,01$ \\
\hline 1975 RoufF & $\begin{array}{l}\text { Karikatúrahumor- } \\
\text { értelmezés }\end{array}$ & Távoli asszociáció & $+0,37 p<0,001$ \\
\hline $\begin{array}{l}1976 \text { BRODZINSKY és } \\
\text { RUBIEN }\end{array}$ & Karikatúracím-adás & Távoli asszociáció & pozitív \\
\hline 1980 CLABBy & $\begin{array}{l}\text { Kampányszlogen- } \\
\text { kitalálás }\end{array}$ & Szokatlan használat & $+0,325 p<0,01$ \\
\hline $\begin{array}{r}1996 \text { HUMKE és } \\
\text { SCHAEFER } \\
\end{array}$ & MSHS & $\begin{array}{l}\text { Frank-féle rajzkiegé- } \\
\text { szítés }\end{array}$ & $+0,77 p<0,01$ \\
\hline 2003 WYCOFF és PRYOR & $\begin{array}{l}\text { SHRQ } \\
\text { CHS }\end{array}$ & CPS & $\begin{array}{r}+0,24 \quad p<0,1 \\
0,00\end{array}$ \\
\hline 2004 Sitton és Pierce & Geográfiai poénadás & Távoli asszociáció & $+0,42 p=0,001$ \\
\hline
\end{tabular}

Gyakran felvetődik, hogy a humor játékos légkört teremt, csökkenti a feszültséget, a gondolkodási rigiditását és serkenti a kreativitást (ZIV, 1976, 1989); a pozitív hangulat (egy filmkomédia nézése) javítja a flexibilitást, eredetiséget (ISEN, DAUbMAN és Nowiczki, 1987; FilipPOWITZ, 2006). A humorprodukció és a kreativitás párhuzamos jelenségek, részben közös szociális, kognitív és érzelmi mögöttes folyamatokkal, de az is elképzelhető, hogy más pszichológiai fogalmakkal, intelligenciával, verbális képességgel, kedélyességgel, személyiségvonásokkal mutatnak együttjárást (O'QUiN és DERKs, 2011). Ahogy arra MARTIN (2007) rávilágít, a kreativitás és a humor között többféle kapcsolat lehetséges, a kutatások pedig eddig egyiket sem tudták cáfolni. A humor és a kreativitás lehet két teljesen kü- 
lönálló vagy két egymást valamennyire átfedő terület, vagy pedig a humor a kreativitás nagyobb halmazának része. Ugyanakkor KÖHLER és RUCH (1996) arra mutatnak rá, hogy a humor megértése, kedvelése és a humor produkciója sem feltétlenül összefüggő folyamatok, így azon vizsgálatok, melyek az általános humorérzék és a kreativitás kapcsolatát vizsgálják, túlzottan összemossák a humor sokrétű fogalmának különböző elemeit.

További szempontot sorolhatunk a humor és kreativitás közötti kapcsolat kérdései közé, s ez a humorstílus. A humorprodukciós képességet az egyéni humorhasználat vagy humorstílus különbségeinek szempontjából szintén indokolt vizsgálnunk - veti fel EDWARDS és MARTIN (2010). Ugyanis kétféle, a pszichológiai jóllétre viszonylag jótékony és jóindulatú (pozitív), illetve kétféle potenciálisan ártalmas hatású (negatív) humorstílus vagy mindennapi humorfunkció különböztethető meg (Martin, Puhlik-Doris, Larsen, Gray és Weir, 2003). Pozitív humorstílusok: 1. kapcsolatépítő, társak felé irányuló (interperszonális) humor: viccmondás, szellemes visszavágások, spontán szellemes ugratásra való hajlandóság, mások szórakozatását célzó, konfliktus- és feszültségoldó, a kohéziót javító humor; 2. énvédő, önirányított (intrapszichés) humor: jóindulatú, erősítő humor, mint például a stresszel való megküzdés eszköze, perspektívát adó humor. Negatív humorstílusok: 3. agresszív, társak felé irányuló humor: másokkal való kapcsolatban az én erősítését célzó, mások kárára vagy ártalmára használt, másokat kritizáló, manipulatív humor, például kigúnyolás, szarkazmus, csúfolódás; 4. énleértékelő (self-defeating), önirányított humor: másokkal való kapcsolat növelését szolgáló, erősen a személynek önmaga rovására történő humoros megnyilvánulása, öngúny, egyfajta védekező elutasítás.

Vizsgálatunkban a pozitív vagy negatív humorstílust mutató személyeknél vizuális és verbális humorprodukciós és kreativitásmérések alkalmazásával kerestünk a kapcsolatot a humor és a kreativitás között. A humorérzéknek csak egyik mutatója a humorprodukció, így azon vizsgálatok, melyek a humorérzék komplex fogalmából indultak ki, szükségszerűen alacsony mértékű kapcsolatot mutattak ki a humorérzék és a kreativitás között, továbbá a negatív humorstílusok valószínüleg nem segítik a kreativitás kibontakozását, mert romboló hatással vannak az énre és a társas kapcsolatokra nézve is. Így azt feltételeztük, hogy a humorprodukciót közvetlenül vizsgálva, valamint a pozitív, illetve negatív humorstílusokat is figyelembe véve szorosabb összefüggés fog mutatkozni a humor és a kreativitás között, mint az eddigi vizsgálatokban.

\section{MÓDSZER}

\section{Személyek}

A vizsgálatban összesen 133 fö vett részt, 43 férfi és 90 nő, hozzávetőleg a fele (50,9\%) egyetemi hallgató; átlagéletkor: 29,5 év. A férfiak és nők átlagéletkora 32,6, illetve 27,54 év. A mintát egyetemi szabadon választható, a humor pszichológiájával foglalkozó kurzus keretében a hallgatók toborozták, így a minta másik 
felét az ő ismerőseik, szüleik adják. A felvevők egy részletes, a tesztfelvétel minden aspektusára (instrukciók, időkorlát, tájékoztatás a vizsgálat céljáról) kétoldalas instrukciós lapot kaptak, melyet követniük kellett a felvétel során.

\section{Méröeszközök}

Kreatív Gondolkodás Teszt - Rajzi Feladat (Test for Creative Thinking/Drawing Development - TCT-DP) (JELLEN és URBAN, 1986; Urban, 2004; URban és JELLEN, 1996). A és B formából álló befejezetlen rajzfeladat, 6 megadott képelemmel (félkör, pont, íves vonal stb.), amelyek közül 1 elem a kereten kívüli. A személynek a megadott elemekből adott időhatáron belül kell egységes kompozíciót készítenie. A teszt értékelése alaklélektani szempontokra épül, 11 értékelési kategóriával; a humor az egyik értékelő kategória. A szempontok kombinációi megfeleltethetők a kreativitástesztek szokásos mutatóinak (originalitás, elaboráció stb.). Vizsgálatunkban csak az A formát és az originalitás- (Uc), fluencia- és az összpontszám- (TCTtotal) mutatót használtuk. A teljes tesztben kapható maximális pontszám: 72. Értékelők közötti reliabilitás: 0,90 körüli; teszt-reteszt reliabilitás: 0,70-0,75; a tesztkönyvben: 0,82 körüli). Hazai adaptáció: KÁRPÁTI és GYEBNÁR (1997).

Karikatúra „Poénadás” Teszt (Cartoon Punchline Production Test - CPPT; KÖHLER és RUCH, 1995, 1996); (Cartoon Captioning Test - CCT, FEINGOLd és Mozella, 1993). A Karikatúra „Poénadás” Teszt (CPPT vagy CCT) a leginkább használt kreatív teljesítménymérés a témában (lásd KozbelT és NisHiOKA, 2010; Edwards és Martin, 2010; Greengross, Martin és Miller, 2011). Feliratok nélküli karikatúrákhoz kell kitalálni azokat viccessé tevő humoros szövegeket. Alskálák: Válaszok száma vagy fluencia (CPPT-NP), szellemesség (CPPT-WP) és eredetiség (CPPT-OP). A válaszokat független értékelők $(\mathrm{N}=14)$ értékelték 9 pontos Likert-skálán humorosság és originalitás szempontjából, összegzésük adta az egyéni mutatókat.

Távoli Asszociáció Teszt (Remote Association Test - RAT, Mednick, 1962, in ZÉTÉNYI, 1989); szemantikailag távoli szavak közötti közös vagy mindkettőhöz egyformán kapcsolódó szavak kitalálásának feladata. A „Szokatlan használat” teszttel együtt a legelterjedtebben alkalmazott kreativitásmérési feladat. Azért ezt a tesztet alkalmaztuk, mert az eddigi vizsgálatok szerint a szokásos kreativitástesztek közül leginkább ez korrelál a humor megértésével (ROUFF, 1975) és a humor produkciójával (Brodzinsky és Rubien, 1976; Treadwell, 1970; Sitton és Pierce, 2004) (lásd 1. táblázat).

Humorstílus Kérdő́i (Humor Styles Questionnaire - HSQ) MARTIN és munkatársai (2003) által, a humorérzék négy általános dimenziójának (humorstílus) mérésére kidolgozott 32 tételes önminősítő ( 7 fokú skála, 1 = egyáltalán nem ért egyet, $7=$ teljesen egyetért) kérdőív. A négy skála (egyenként 8-8 tétel) belső konzisztencia értékei (Cronbach- $\alpha$ ) 0,77-0,81 közöttiek, teszt-reteszt reliabilitása 0,800,85 közötti. Magyar változatot Konstantin és Séra készíttette (KonstanTin, 2005); reliabilitási adatai a humorstílusok sorrendjében: Kapcsolatépítő: $\alpha=0,81$; Énvédő: $\alpha=0,70$; Agresszív: $\alpha=0,77$; Énleértékelő: $\alpha=0,62$ (TiSLJÁr, 2011). 
Többdimenziós Humorérzék Skála (Multidimensional Sense of Humor Scale MSHS, THORSOn és POWEll (1993a, b; magyar változat: BALOG és SÉRA, 1998). 24 tételes önjellemzős kérdốv (5 fokú Likert-skála) a „humorérzék” vizsgálatára, négy skálával. A skálák: 1. humor kreativitás és szociális használat (MSHS-HC, 11 tétel), például „Más emberek kérik, hogy mondjak mulatságos dolgokat”; 2. a humor megküzdésre való használata (MSHS-CH, 7 tétel); 3. a humoros személyek kedvelése, elismerése (MSHS-Att, 4 tétel) és 4. a humor élvezete (MSHS-HA, 2 tétel). Eredeti vizsgálat: Cronbach- $\alpha=0,91$. Az MSHS-HC (humorkreativitás) alskálával a CPPT-NP $r=0,23$ értékben korrelált, WP-vel (szellemesség) 0,08, OPvel (originalitás) 0,08 (KÖHLER és RUCH, 1996), vagyis csak a fluenciamutató korrelált valamelyest, míg az önbeszámolós kérdőíven mutatott humorérzék a szellemességtől és az eredetiségtől jobbára függetlennek mutatkozott.

\section{Eljárás}

Előbb a kreativitástesztek (Kreatív Gondolkodási Rajzos Teszt, Karikatúra Humorprodukciós Teszt és a Távoli Asszociáció Teszt), majd a humorskálák (Humorstílus Kérdőív, Többdimenziós Humorérzék Skála) kitöltésére került sor, egy ülésben, egyéni felvételben. Időtartama kb. 1 óra volt. Az általános instrukció a humorosság és az ötletesség kapcsolatának vizsgálatára kérte fel a résztvevőket. A vizsgálatban ehelyütt nem részletezett mentális egészségre, továbbá a gelotofóbia (nevetségessé válástól való félelem) mérésére vonatkozó 15 tételes kérdőívet is kitöltöttek a vsz-ek. A mintát egyetemi szabadon választható, a humor pszichológiájával foglalkozó kurzus keretében a hallgatók toborozták. A felvevők egy kétoldalas instrukciós lapot kaptak, melyet követniük kellett a felvétel során.

\section{EREDMÉNYEK ÉS KÖVETKEZTETÉSEK}

Humorstílus A Humorstílus Kérdőív (HSQ) esetében a Cronbach- $\alpha$ 0,67 és 0,84 közötti értékű volt. A kérdőív átlagai és szórásait a 2. táblázat tartalmazza. Feltűnő, hogy saját mintákban mind az eredeti adatokhoz, mind pedig más hazai vizsgála-

2. táblázat. A Humorstílus Kérdőív átlagai és szórásai

\begin{tabular}{|l|c|c|c|}
\hline \multirow{3}{*}{ Humorstílus } & $\begin{array}{c}\text { MARTIN és mtsai (2003) } \\
\mathrm{n}=1195\end{array}$ & $\begin{array}{c}\text { TISLJÁR R. (2010) } \\
\mathrm{n}=217\end{array}$ & $\begin{array}{c}\text { Saját vizsgálat } \\
\mathrm{n}=133\end{array}$ \\
\cline { 2 - 4 } & átlag (szórás) & átlag (szórás) & átlag (szórás) \\
\hline Kapcsolatépítő & $46,4 \quad(7,17)$ & $45,9(7,7)$ & $41,455(6,52)$ \\
\hline Énvédő & $37,3 \quad(8,33)$ & $37,4 \quad(8,2)$ & $37,60 \quad(9,26)$ \\
\hline Agresszív & $28,5 \quad(8,79)$ & $32,1 \quad(8,8)$ & $29,57 \quad(8,00)$ \\
\hline Énleértékelő & $25,9(8,1)$ & $29,0 \quad(8,1)$ & $29,46 \quad(8,09)$ \\
\hline
\end{tabular}


tokhoz képest a Kapcsolatépítő alskála átlaga esetében jóval alacsonyabb (Cohen-d $=0,50)$, az Énleértékelő humorhasználat esetében pedig a hazai mintákban magasabb érték (Cohen-d $=0,43)$ mutatkozott.

Nemek különbsége A humorstílusok közül csak mindkét negatív humorhasználatban (Agresszív és Énleértékelő) és az összevont negatív humorstílusban (t(155) $=1,974, p=0,050)$ volt tendencia szintjén kimutatható különbség a férfiak irányába, vagyis a férfiak inkább élnek negatív humorhasználati módokkal, mint a nők.

\section{Kreativitástesztek}

A Távoli Asszociáció Teszt átlagait és szórásait a 3. táblázat tartalmazza. A teszt esetében egyik mutató (originalitás, flexibilitás és fluencia) és a kombinált mutatók (átlagoriginalitás $=$ orig/flu; relatív flexibilitás $=$ flex/flu) tekintetében sem mutatkozott szignifikáns különbség a nemek között.

3. táblázat. A Távoli Asszociáció Teszt átlagai és szórásai

\begin{tabular}{|l|c|c|}
\hline \multicolumn{1}{|c|}{ Távoli asszociáció } & Átlag & Szórás \\
\hline Originalitás & 4,433 & 2,994 \\
\hline Flexibilitás & 6,962 & 2,784 \\
\hline Fluencia & 8,774 & 4,388 \\
\hline Átlagoriginalitás & 0,505 & 0,682 \\
\hline Relatív flexibilitás & 0,793 & 0,634 \\
\hline
\end{tabular}

A Kreatív Gondolkodás Teszt - Rajzi feladat (TCT-DP) 14 értékelési szempontból tevődik össze, amit összegegezve, 15 értékelési mutató állt rendelkezésünkre. Ez utóbbi bár kiadja a teszt teljesítményének összességét, a teszt szerzői szerint a minőségi jellemzéshez mindegyik szempont szükséges, mert a létrejött alkotás több, mint a részeinek az összege, akárcsak a kreatív gondolkodás (URBAN, 2004). A Kreatív Gondolkodási Rajzos Teszt adatait a 4. táblázat tartalmazza. A teszt reliabilitásértékei a jelenlegi mintában is jók, $\alpha=0,725$. A teszt összpontszáma szoros együtt járást mutat a Távoli Asszociáció Teszt originalitás-, flexibilitás- és fluenciaértékeivel, sorrendben originalitás: $r=0,231, p<0,008$; fluencia: $r=0,259$, $p<0,003$; és flexibilitás: $r=0,296, p<0,001$ szinten.

A nemek között nemcsak az összpontszámban volt szignifikáns különbség (Welch-d $=-2,628, p<0,01$ ), hanem további 5 mutatóban is rendre a nők mutattak jobb teljesítményt. Ez az eredmény ellentmondásban van a teszt készítőinek (URBAN, 2004) a kutatási eredményeivel, továbbá a korábbi magyar standard készítésekor (KÁRPÁTI és GYEBNÁR, 1997) szerzett tapasztalatokkal, amelyek során nem találtak szignifikáns eltérést a nemek között a tesztben. 


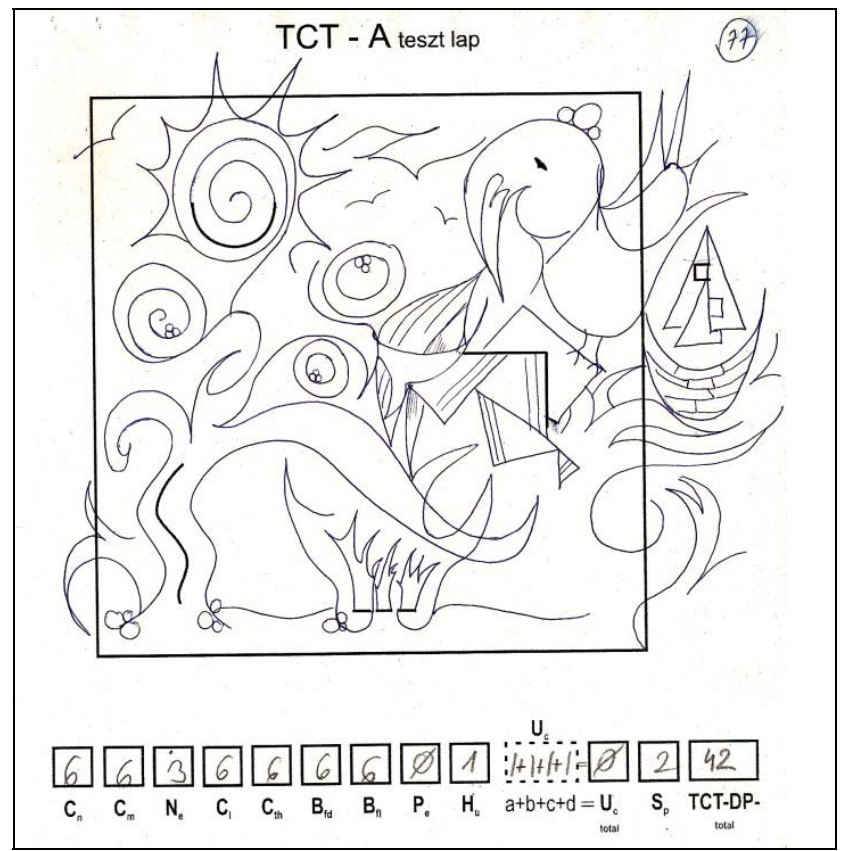

2. ábra. Egy példa a Kreatív Gondolkodási Rajzos Teszt mostani vizsgálatából

4. táblázat. A Kreatív Gondolkodási Rajzos Teszt (TCT-DP) mutatóinak átlagai és nemi különbségei (eredeti jelzések)

\begin{tabular}{|c|c|c|c|c|c|c|c|}
\hline TCT-DP mutatók & Átlag & Szórás & Nem & $\mathrm{N}$ & Átlag & Szórás & Welch-d és $p$ \\
\hline \multirow{2}{*}{$\begin{array}{l}\text { TCT_Ne } \\
\text { (új elem) }\end{array}$} & \multirow{2}{*}{1,932} & \multirow{2}{*}{1,951} & férfi & 58 & 1,55 & 1,667 & \multirow{2}{*}{$\begin{array}{l}\text { Welch-d }=-2,537 \\
p<0,012^{* *}\end{array}$} \\
\hline & & & nő & 104 & 2,32 & 2,119 & \\
\hline \multirow{2}{*}{$\begin{array}{l}\text { TCT_Cl } \\
\text { (vonalkapcsolat) }\end{array}$} & \multirow{2}{*}{3,068} & \multirow{2}{*}{2,274} & férfi & 58 & 2,48 & 2,071 & \multirow{2}{*}{$\begin{array}{l}\text { Welch-d }=-2,699 \\
p<0,008^{*}\end{array}$} \\
\hline & & & nő & 104 & 3,44 & 2,335 & \\
\hline \multirow{2}{*}{$\begin{array}{l}\text { TC_Cth } \\
\text { (témakapcsolat) }\end{array}$} & \multirow{2}{*}{3,353} & \multirow{2}{*}{2,641} & férfi & 58 & 2,78 & 2,689 & \multirow{2}{*}{$\begin{array}{l}\text { Welch-d }=-2,163 \\
p<0,033^{*}\end{array}$} \\
\hline & & & nő & 104 & 3,72 & 2,627 & \\
\hline \multirow{2}{*}{$\begin{array}{l}\text { TC_Pe } \\
\text { (perspektíva) }\end{array}$} & \multirow{2}{*}{0,805} & \multirow{2}{*}{1,357} & férfi & 58 & 0,52 & 0,822 & \multirow{2}{*}{$\begin{array}{l}\text { Welch-d }=-2,335 \\
p<0,021^{*}\end{array}$} \\
\hline & & & nő & 104 & 0,93 & 1,443 & \\
\hline \multirow{2}{*}{$\begin{array}{l}\text { TC_Sp } \\
\text { (sebesség) }\end{array}$} & \multirow{2}{*}{0,880} & \multirow{2}{*}{1,652} & férfi & 58 & 0,41 & 1,124 & \multirow{2}{*}{$\begin{array}{l}\text { Welch-d }=-3,432 \\
p<0,001^{* * *}\end{array}$} \\
\hline & & & nő & 104 & 1,21 & 1,831 & \\
\hline \multirow{2}{*}{ TCT összérték } & \multirow{2}{*}{21,86} & \multirow{2}{*}{10,46} & férfi & 58 & 19,28 & 9,307 & \multirow{2}{*}{$\begin{array}{l}\text { Welch-d }=-2,628 \\
p<0,010^{* *}\end{array}$} \\
\hline & & & nő & 104 & 23,53 & 10,822 & \\
\hline
\end{tabular}


A 15 mutatóból 6 esetben jelentősen jobb teljesítményt mutattak a nők ebben a mintában. Úgy tűnik, hogy jobban megfogta őket az alkotásnak ez a formája, több új elemmel egészítették ki a megadott képelemeket, és mind a vonalkapcsolatok, mind a téma szempontjából jobban tudtak egységet létrehozni, alkalmazni a perspektivikus kifejezést, és mindez nem ment a sebesség rovására sem.

A faktorelemzés a Kreatív Gondolkodási Rajzos Teszt 14 értékét tartalmazza (5. táblázat). A kapott öt faktorból leginkább három különíthető el úgy, hogy több elem magas faktorsúllyal kapcsolható össze. Az első faktorba tartozó szempontok $(\mathrm{Cl}=$ vonalkapcsolat; $\mathrm{Cth}=$ témakapcsolat; $\mathrm{Ne}=$ új elemek; $\mathrm{Sp}=$ sebesség; $\mathrm{Pe}=$ perspektíva) a rajzos teszt kreatív produkció vizuális egységét, minőségét adják, egyfajta elaborációnak foghatjuk fel. A második faktor mennyiségi jellegü, az előre megadott ábratöredékek felhasználását mutatja $(\mathrm{Cn}=$ folytatás $; \mathrm{Cm}=$ kiegészítés; Bfd = körvonalmegőrző részletfüggő). Ezt a faktort rokonnak tekinthetjük a fluenciamutatóval, bár itt az értékelésnél egy felső pontérték van, ami behatárolja a válaszszámot. A harmadik faktor öt elemet tartalmaz, kettő igen nagy faktorsúlyú: a nem szokványos megoldás (Ucb) bármilyen szürrealista, fiktív és/vagy absztrakt elemek, vagy rajzok mutatója, míg a humor $(\mathrm{Hu})$ a humoros választ, érzelmi jelleget értékeli. Ezt a faktort tulajdonképpen inkongruenciafaktornak nevezhetnék, hiszen mind a szürreális, mind a humoros ingerek közös nevezője az azokban megbúvó vagy éppen az azokat megalapozó, a lehetetlen és a valóságos összeolvadását megjelenítő inkongruencia. A faktoranalízisben nem kerültek egy csoportba a teszt konvenciómentességet megragadni hivatott mutatói. Ezeken belül a leginkább originalitást értékelő szempont, az Ucd ebbe a harmadik faktorba tartozhat, de értéke nem érte el a besoroláshoz szükséges mértéket. Sajnos így a tesztben nem azonosíthatunk egyértelműen originalitásnak megfeleltethető faktort.

5. táblázat. A Kreatív Gondolkodási Rajzos Teszt (TCT) faktoranalízisének eredményei

\begin{tabular}{|l|c|c|c|c|c|}
\hline & 1. & 2. & 3. & 4. & 5. \\
\hline Vonal kapcsolat (Cl) & 0,898 & & & & \\
\hline Téma kapcsolat (Cth) & 0,873 & & & & \\
\hline Új elem (Ne) & 0,729 & & & & \\
\hline Sebesség (Sp) & 0,643 & & 0,309 & & \\
\hline Perspektíva (Pe) & 0,438 & & & $-0,309$ & 0,400 \\
\hline Folytatás (Cn) & & 0,887 & & & \\
\hline Kiegészítés (Cm) & & 0,767 & & & \\
\hline Körvonalmegőrző részletfüggő (Bfd) & & 0,701 & & & \\
\hline Nem szokványosA (Uca) & & & 0,783 & & \\
\hline Humor (HU) & & & 0,782 & & \\
\hline Nem szokványos-d (Ucd) & & & 0,405 & 0,391 & $-0,376$ \\
\hline Nem szokványos-b (Ucb) & & & & 0,781 & \\
\hline Körvonal megőrző részletfüggetlen (Bfi) & & 0,384 & & 0,634 & \\
\hline Nem szokványos-c (Ucc) & & & 0,311 & & 0,799 \\
\hline
\end{tabular}


Az első és ez utóbbi faktorokat vontuk be a további elemzésekbe az összpontszámon felül, míg a fluencia névvel összevontban csak a folytatás $(\mathrm{Cn})$ és kiegészítés $(\mathrm{Cm})$ mutatók szerepelnek.

Karikatúra „Poénadási” Teszt (CPPT) kreativitásmutatói: CP-NP (fluencia), CPWP (humor/szellemesség), CP-OP (originalitás). Három különböző értékelővel értékeltettük a humorprodukciókat, az értékelők közötti korreláció az originalitás és szellemesség megítéléseiben 0,60 körüliek. A mutatók egyikében sem, és az átlagos originalitásban (CP-atl.o; CP-OP/CP-NP) sem kaptunk különbséget a férfiak és nők között.

A Karikatúra-poénadás teszt a humorprodukciót mint a kreativitás és a humorérzék egyik fontos jellemzőjét hivatott megragadni. Megvizsgáltuk az együttjárást a Kreatív Gondolkodási Rajzos Teszt szürreális, absztrakt megoldást és a humor szempontot tartalmazó faktorával, feltételezve, hogy ezek mutathatnak leginkább kapcsolatot a poénadással. Feltételezésünket az összehasonlítás nem igazolta a poénadással kapcsolatban (valószínủleg azért, mert a humor több összetevőt tartalmaz az inkongruencia „egyszerű” megragadásánál, lényegében attól, hogy valami inkongruens, még nem biztos, hogy humoros), de a kapcsolatépítő humor stílussal igen $(r=0,171, p<0,05)$.

Talán nem meglepő módon a karikatúra-poénadás kreatív képessége mind a szellemesség, viccesség (CP-Wp-átl ; $r=0,234 p<0,01$ ), mind az eredetiség (CpOP-átl; $r=0,225 \quad p<0,01)$ teljesítményében szignifikáns együttjárást mutatott a Kreatív Gondolkodási Rajzos Teszt (TCT-DP) első faktorával. Ez a faktor jelenti a vizuális kreativitás minőségét, az elaborációt, melynek során a töredékes elemekből a képalkotás egységbe szerveződése történik. Ez az eredmény nemcsak a humor analitikus magyarázatait látszik alátámasztani, mint egy tudattalan impulzus átdolgozott, szociálisan kifejezhető formája, hanem az alakélektan belátással kapcsolatos elképzeléseit is, amiben a részek egyszerre csak összeállnak egy új minőségű egésszé.

Többdimenziós Humorérzék Skála (MSHS) egy 24 tételből álló önjellemző kérdőív, amelyben a személyek saját humorérzékükről nyilatkoznak. A négy alskálából három (a humorprodukció és szociális használata; a humor felhasználása megküzdésre, alkalmazkodásra; illetve a humoros személyek kedvelése) megbízhatónak bizonyult, míg a negyedik (a humor élvezése) skálát kevésbé találtuk megbízhatónak. Összességében a teszt kreativitás és coping skáláinak, valamint az egész teszt 0,90 körüli Cronbach- $\alpha$ értékei nagyon jók. Csak a kreativitás alskála mutat szignifikáns nemi különbséget $p=0,045$ szinten, vagyis önbeszámolós skálán mutatható csak ki nemi különbség a humor és a kreativitás vonatkozásában, független, a válaszadók nemét nem ismerő értékelők humorprodukció-értékelése alapján nem.

A Többdimenziós Humorérzék Skála (MSHS) kreativitás alskálája (ami a Távoli Asszociáció Teszt originalitásmutatójával $r=0,9$-es korrelációt mutatott) és a poénadás között csak a fluenciában van jelentős korreláció $(r=0,213 p<0,05)$, vagyis pontosan ugyanazokat az eredményeket kaptuk, amiket a karikatúra-poénadási teszt (CPPT) szerzői is a teszt validitás- és reliabilitásvizsgálata során (KöHLER és RUCH, 1995, 1996). 
6. táblázat. Nemi különbségek az MSHS (Multidimensional Sense of Humor Scale, Többdimenziós Humorérzék Skála) tesztben

\begin{tabular}{|l|c|r|r|r|c|}
\hline & Nem & $\mathrm{N}$ & Átlag & Szórás & \multirow{2}{*}{$p$-érték } \\
\hline \multirow{2}{*}{ Kreativitás } & férfi & 58 & 27,93 & 8,137 & \multirow{2}{*}{0,045} \\
\cline { 2 - 5 } & nő & 103 & 25,32 & 7,699 & \\
\hline \multirow{2}{*}{ Megküzdés } & férfi & 58 & 18,91 & 5,627 & \multirow{2}{*}{0,142} \\
\cline { 2 - 5 } & nő & 104 & 17,56 & 5,605 & \\
\hline \multirow{2}{*}{ A humor élvezete } & férfi & 58 & 6,86 & 1,083 & \multirow{2}{*}{0,629} \\
\cline { 2 - 5 } & nő & 104 & 6,95 & 1,161 & \multirow{2}{*}{0,891} \\
\hline \multirow{2}{*}{ Humor iránti attitűd } & férfi & 58 & 12,62 & 2,834 & \multirow{2}{*}{0,080} \\
\cline { 2 - 5 } & nő & 104 & 12,56 & 2,779 & \\
\hline \multirow{2}{*}{ Összegzett mutató } & férfi & 58 & 66,33 & 14,864 & \\
\cline { 2 - 5 } & nő & 103 & 62,41 & 12,742 & \\
\hline
\end{tabular}

A Többdimenziós Humorérzék Skála (MSHS) kreativitás alskálája nagyon magas együttjárást mutat a humorstílust mérő kérdőív (HSQ) skáláival. Sorrendben: Kapcsolatépítő $(r=0,634 p<0,01)$, Énvédő $(r=0,519 p<0,01)$, Agresszív $(r=0,338$ $p<0,01)$, Énleértékelő $(r=0,398 p<0,01)$; pozitív humorstílusok: $r=0,645 p<0,01$; negatív humorstílusok: $r=0,434 p<0,01)$.

Mint a 7. táblázatban látható a Többdimenziós Humorérzék Skála (MSHS) és a Kreativitás Gondolkodási Rajzos Teszt (TCT-DP) mutatói között több korreláció volt megállapítható, jóllehet leginkább a nem megfelelő Cronbach- $\alpha$ értékkel bíró humor élvezete alskálával, továbbá a megbízható skálákkal mutatott korrelációk meglehetősen alacsonyak.

7. táblázat. A Kreativitás Gondolkodási Rajzos Teszt (TCT) és a Többdimenziós Humor Skála (MSHS) alskálái közötti korrelációk

\begin{tabular}{|c|c|c|c|c|c|}
\hline & \multicolumn{5}{|c|}{ Többdimenziós Humor Skála (MSHS) } \\
\hline & 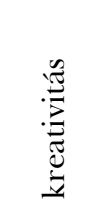 & 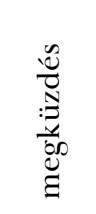 & 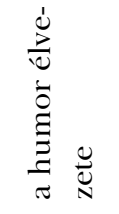 & 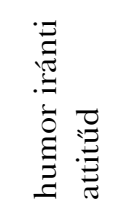 & 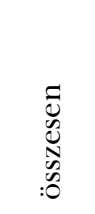 \\
\hline TCT összegzett mutató & 0,076 & 0,143 & $0,231^{* *}$ & $-0,010$ & 0,120 \\
\hline TCT fluencia & $0,175^{*}$ & 0,098 & $0,303^{* *}$ & 0,137 & $0,196^{*}$ \\
\hline \multicolumn{6}{|l|}{ Vizuális kreativitás } \\
\hline$(\mathrm{CL}+\mathrm{CTH}+\mathrm{NE}+\mathrm{SP}+\mathrm{PE})$ & 0,027 & 0,170 & $0,261^{* *}$ & 0,092 & 0,126 \\
\hline \multicolumn{6}{|l|}{ Szürreális humoros } \\
\hline$(\mathrm{UB}+\mathrm{HU})$ & 0,038 & 0,075 & 0,120 & $-0,083$ & 0,046 \\
\hline
\end{tabular}


A Kreativitás Gondolkodási Rajzos Teszt (TCT) több mutatója/faktora szignifikáns kapcsolatot jelzett az egyes humorstílusokkal (8. táblázat), ugyanakkor e korrelációk is meglehetősen alacsonyak.

8. táblázat. A Kreativitás Rajzos Teszt (TCT) faktorai és a humorstílusok (HSQ, Humor Styles Questionnaire alskálák) közötti korrelációk

\begin{tabular}{|c|c|c|c|c|c|c|}
\hline & $\begin{array}{c}\text { HSQ } \\
\text { kapcsolati }\end{array}$ & $\begin{array}{c}\text { HSQ } \\
\text { énvédő }\end{array}$ & $\begin{array}{c}\mathrm{HSQ} \\
\text { agresszív }\end{array}$ & $\begin{array}{c}\text { HSQ } \\
\text { énleértékelo” }\end{array}$ & $\frac{\text { HSQ pozit }}{\text { h u m or }}$ & $\begin{array}{l}\text { SQ negatív } \\
\text { ználat }\end{array}$ \\
\hline $\begin{array}{l}\text { TCT összeg- } \\
\text { zett mutató }\end{array}$ & $0,211^{*}$ & 0,139 & 0,163 & 0,000 & $0,193^{*}$ & 0,093 \\
\hline TCT fluencia & $0,261^{* *}$ & 0,126 & 0,096 & $-0,052$ & $0,208^{*}$ & 0,024 \\
\hline $\begin{array}{l}\text { Vizuális } \\
\text { kreativitás }\end{array}$ & & & & & & \\
\hline $\begin{array}{l}\mathrm{CL}, \mathrm{CTH}, \\
\mathrm{NE}, \mathrm{SP}, \mathrm{PE})\end{array}$ & 0,145 & 0,066 & 0,072 & $-0,059$ & 0,149 & 0,006 \\
\hline $\begin{array}{l}\text { Szürreális } \\
\text { humoros }\end{array}$ & & & & & & \\
\hline$(\mathrm{UB}+\mathrm{HU})$ & $0,176^{*}$ & $-0,009$ & 0,133 & 0,169 & 0,084 & $0,178^{*}$ \\
\hline
\end{tabular}

Miközben a vizuális minőséget képviselő faktor a poénadással mutatott összefüggést, a humorstílushoz nem kapcsolódik az adataink alapján. Viszont a TCT-DP kreativitásteszt összpontszáma, a fluenciafaktor és a humort, szürreális absztrakt megoldást tartalmazó faktor összefügg a kapcsolatépítő humorral. A TCT total és fluencia a pozitív humorstílussal is mutat együttjárást, míg a szürreális-humoros faktor a negatív humorstílushoz társul, és egyúttal a kapcsolatépítő skálához is csatlakozik, ami aláhúzza azt az összefüggést, hogy a humor attól, hogy negatív, még humor, és így ugyan nem annyira pozitív hatású, de nem is egyértelműen negatív (csak a pozitív használati módokhoz képest).

\section{MEGBESZÉLÉS}

A tanulmány bevezető részében felvetettük, hogy a humorprodukciónak és a kreativitásnak olyan fogalmilag közös összetevői vannak, mint az inkonguitásfeloldás és a belátás (váratlan felfedezés) elemei. Az utóbbi évek idegtudományi kutatásai feltárták a humor élvezése és a belátás neurális alapjait. Legújabban AMIR, BIEDERMAN, WANG és XU (2013) funkcionális mágneses rezonancia vizsgálatukban firkarajzok (droodle) humoros és nem humoros (értelmezési) felfedezéseinek manipulálásával különbségekre mutattak rá a „ha-ha!” és az „aha!” élmények neu- 
rális hátterében. Távoli fogalmak összekapcsolásával és váratlan jutalmazással/megerősítéssel kapcsolatos fokozott aktivitás - sorrendben - a temporális póluson és a temporális-occipitális lebeny találkozásán, illetve a mediális prefrontális kéregben csak a humororos feltételnél mutatkozott. A szerzők értelmezése szerint: „A vidám nevetés a távoli ötletekkel való kapcsolat következménye lehet, amely fokozott aktivációt okoz az asszociációs területen és a klasszikus jutalmazási területekben" (AMIR és mtsai, 2013, 1).

Vizsgálatunkban a korábbi eredmények vonalán enyhébb pszichometriai kapcsolatot mutattunk ki eddig még nem vizsgált humoros feltaláló elemet tartalmazó eljárások alkalmazásával, mint a Kreatív Gondolkodási Rajzos Teszt (TCT-DP; JELLEN és URBAN, 1986) és a karikatúra-poénadási teszt (CPPT; KÖHLER és RUCH, 1995) a kreativitásmutatók és a humorjegyek között. Eredményeink szerint a karikatúra-poénadás kreatív képessége mind a szellemesség, viccesség, mind az eredetiség teljesítményében szignifikáns együttjárást mutatott a Kreatív Gondolkodási rajzos Teszt vizuális kreativitási minőséggel, elaborációval és belátással kapcsolatos faktorával. A kreativitás- és humorprodukció-mérések korrelációja általában gyenge, O'QUiN és DERKs (1997) összefoglalása szerint: 0,34. Saját adataink is arra utalnak, mint amilyen következtetésre O'Quin és Derks is jutott, hogy a humorprodukció és a kreativitás, habár hasonló mentális folyamatokra támaszkodnak, melynek alapja az elaboráció lehet, mégis eltérő képességeknek tekinthetők. Valószínű, hogy a humoros és nem humoros belátás/felfedezés kognitív mechanizmusainak további vizsgálatai, amelyre már történtek próbálkozások (Kozbelt és NishiokA, 2010), közelebb visz ennek a kérdésnek a megértéséhez.

A korábbi vizsgálatok a humorérzék kreatív aspektusait mérő kérdőívek között nem vagy csak gyenge a korrelációt állapítottak meg (KÖHLER és RUCH, 1996). Vizsgálatunkban a Többdimenziós Humorérzék Skála kreativitás alskálája, jóllehet igen szoros együttjárást adott $(r=0,900)$ a Távoli Asszociáció Teszt originalitás mutatójával, azonban a karikatúra-poénadási feladatban csak a fluencia tekintetében volt szignifikáns korreláció $(r=0,213)$. Ezzel kapcsolatban felvethető, hogy ez részben abból fakadhat, hogy a Többdimenziós Humorérzék Skála önbeszámolós, míg a karikatúra humorprodukciós mérés viselkedéses eljárás, így az előbbi inkább torzít és/vagy méri a hétköznapi társas helyzetekben megjelenő humorformákat, míg a karikatúrák szövegezése meglehetősen mesterséges szituáció.

A humorstílusok kérdőíves kimutatásával kapcsolatban megállapíthatjuk, hogy hasonlóan CAYIRDAG és ACARB (2010) eredményeihez, akik csak a kreativitás (szokatlan használat) és az agresszív stílus, továbbá az énvédő stílus és a fluencia között kaptak pozitív korrelációt, saját adataink is csak részlegesnek és ellentmondónak tekinthetők. Pozitív korrelációt találtunk a kapcsolatépítő stílus és a fluencia összmutatója között, a Kreatív Gondolkodás Teszt átlagoriginalitás és a negatív humorstílusok között. A nagyszámú ötlet együtt járhat a társas életben szükséges leleményességgel, ami a kapcsolataink építését segítő humorhasználat egyik eleme is lehet. Az originalitás és a negatív humor összefüggésének hátterében az állhat, hogy a tapasztalatra nyitott személyek általában kreatívabbak is (például MCCREA, 1987; SNEED, MCCRAE és FundER, 1998), élménykeresőbbek, talán kevésbé foglalkoztatja őket a humoruk másokra, illetve önmagukra gyakorolt hatása. 
Jelen vizsgálat a humor és a kreativitás több aspektusát vizsgálta egyszerre, önbeszámolós és független értékelők segítségével is nyertünk adatokat. A legfőbb problémát a humor nem természetes kontextusban való mérése jelenti, noha a humorhasználatunk legnagyobb részét a hétköznapi diskurzusainkban megjelenő humor adja (MARTIN, 2007). Elképzelhető, hogy a pontos instrukció ellenére nem minden felvevő követte az eljárást (például nem alkalmazott időkorlátot), így az eredmények torzulhattak. Ezen kívül sok mérőeszközt alkalmaztunk, így lehet, hogy bizonyos eredmények statisztikai műtermékek csupán, jóllehet az eredményeink a szakirodalomban fellelhető eredményeknek megfelelnek.

A jövőbeni kutatásoknak sokkal inkább kéne a humor és a kreativitás mindennapi életben megjelenő összefüggésire fókuszálni, továbbá ígéretes kutatási irány lehet a kreatív szervezetek és a nem kreatív szervezetekben megjelenő humorhasználati módok, humorstílusok összehasonlítása.

\section{IRODALOM}

Amabile, T. M. (1996). Creativity in Context: Update to the Social Psychology of Creativity. Boulder, CO: Westview.

Amir, O., Biederman, I., WAng, Z., \& Xu, X. (2013). Ha Ha! Versus Aha! A direct comparison of humor to non humorous insight for determining the neural correlates of mirth. Cerebral Cortex, doi: 10.1093/cercor/bht343. Letöltve: 2014. július 15.

BABAD, E. (1974). A multi-method approach to the assessment of humor: A critical look at humor tests. Journal of Personality, 42(4), 618-631.

BALOG P. és SÉRA L. (1998). A humor mint megküzdési stratégia. Végeken, 9(1), 14-23.

BERGEN, D. (2009). Gifted children's humor preferences, sense of humor, and comprehension of riddles. International Journal of Humor Research, 22(4), 419-436.

Bressler, E. R., Martin, R. A., \& Balshine, S. (2006). Production and appreciation of humor as sexually selected traits. Evaluation and Human Behavior, 27(2), 121-130.

Brodzinsky, D., \& Rubien, J. (1976). Humor production as a function of sex of subject, creativity, and cartoon content. Journal of Consulting and Clinical Psychology, 44(4), 597600.

CAyirdaG, N., \& ACARb, S. (2010). Relationship between styles of humor and divergent thinking. Procedia - Social and Behavioral Sciences, 2, 3236-3240. Letöltve: 2013. március 13-án: http://www.sciencedirect.com/science/article/pii/S1877042810005343.

Clabby, J. F. (1980). The wit: a personality analysis. Journal of Personality Assessment, 44(3), $307-310$

Derks, P., \& Hervas, D. (1988). Creativity in humor production: Quantity and quality in divergent thinking. Bulletin of the Psychonomic Society, 26(1), 37-39.

DewitTe, S., \& Verguts, T. (2001). Being funny: a selectionist account of humor production. International Journal of Humor Research, 14(1), 37-53.

EDWARDS, K. R., \& Martin, R. A. (2010). Humor creation ability and mental health: Are funny people more psychologically healthy? Europe's Journal of Psychology, 6(3), 196212 
FABRizi, M. S., \& POllio, H. R. (1987). Are funny teenagers creative? Psychological Reports, $61,757-761$.

FEIngOld, A., \& MAZzella, R. (1993). Preliminary validation of a multidimensional model of wittiness. Journal of Psychology, 61(3), 439-456.

Filipowitz, A. (2006). From pozitive affect to creativity: The surprizing role of surprise. Creativity Research Journal, 18(2), 141-152.

GREenberG, N. (2004). The beast at play: The neuroethology of creativity. In R. CLements, \& R. Fiorentino (Eds.), The Child's Right to Play: A Global Approach (309-372). Wesport, CT: Praeger Press.

Greengross, G., \& Miller, G. (2011). Humor ability reveals intelligence, predicts mating success, and is higher in males. Intelligence, 39(4), 188-192.

Greengross, G., Martin, R. A., \& Miller, G. (2011). Personality traits, intelligence, humor styles, and humor production ability of professional stand-up comedians compared to college students. Psychology of Aesthetics, Creativity, and the Arts, 6(1), 74-82.

Holt, D. G. (1996). Positively humorous: Teaching gifted middle school students to use positive humor to cope with stress. Gifted Child Today, 19(1), 18-21, 38-39.

Holt, D. G., \& Willard-Holt, C. (1995). An exploration of the relationship between humor and giftedness in students. International Journal of Humor Research, 8(3), 257-271.

Humke, E. E., \& Schaefer, C. (1996). Sense of humor and creativity. Perceptual and Motor Skills, 82(2), 544-546.

Isen, A. M., Daubman, K. A., \& Nowicki, G. P. (1987). Positive affect facilitates creative problem solving. Journal of Personality and Social Psychology, 52(6), 1122-1131.

Jellen, H. G., \& Urban, K. K. (1986). The TCT-DP (Test for Creative Thinking-Drawing Production): An instrument that can be applied to most age and ability groups. Creative Child and Adult Quarterly, 11(3), 138-155.

KÁRpÁTi A. és GYebnár V. (1997): A TCT/DP rajzos kreatív gondolkodás teszt. Pszichológia, $17(1), 23-52$.

Kaufman, S. B., \& Kozbelt, A. (2009). The tears of a clown: Understanding comedy writers. In S. B. Kaufman, \& J. C. Kaufman (Eds.), The Psychology of Creative Writing (8097). Cambridge: Cambridge University Press.

Kaufman, S. B., Kozbelt, A., Bromley, M. L., \& Miller, G. F. (2008). The role of creativity and humor ability in human mating. In G. GEHER, \& G. F. Miller (Eds.), Mating Intelligence: Theoretical and Empirical Insight into Intimate Relationships (227-262). Mahwah, NJ: Erlbaum.

KOeSTLER A. (1964/1998). A teremtés. Budapest: Európa.

Koestler, A. (1967). The three domains of creativity. In J. F. H. Bugental (Ed.), Challenges of Humanistic Psychology (30-40). New York: McGraw-Hill.

KÖHler, G., \& RuCH, W. (1995). On the assessment of 'wit': The Cartoon Punch line Production Test. Poster presented at the 3rd European Conference of Psychological Assessment, Aug. 27-30, Trier, Germany.

KöHLER, G., \& RUCH, W. (1996). Sources of variance in current sense of humor inventories: How much substance, how much method variance? International Journal of Humor Research, 9(3-4), 363-397.

Konstantin M. (2005). A humorstílus vizsgálata a baráti kapcsolatban. Szakdolgozat, ELTE PPK. Budapest: Pszichológiai Intézet. 
Kozbelt, A., \& NishiokA, K. (2010). Humor comprehension, humor production, and insight: An explanatory study. International Journal of Humor Research, 23(3), 375-401.

Kudrowitz, B. M. (2010). Haha and aha! Creativity, idea generation, improvisational humor, and product design. PhD in Mechanical Engineering, MIT. Letöltve: 2013. március 13-án: http://hdl.handle.net/1721.1/61610.

Li, N. P., Griskevicius, V., Durante, K. U., Jonason, P. K., Pasisz, D. J., \& Aumer, K. (2009). An evolutionary perspective on humor: Sexual selection or interest indicator? Personality and Social Psychology Bulletin, 35(7), 923-936.

MARTIN, R. A. (2007) The psychology of humor. Burlington, MA: Elsevier.

Martin, R. A., Puhlik-Doris, P., Larsen, G., Gray, J., \& Weir, K. (2003). Individual differences in uses of humor and their relation to psychological well-being: Development of the Humor Styles Questionnaire. Journal of Research in Personality, 37(1), 48-75.

MCCREA, R. R. (1987). Creativity, divergent thinking, and openness to experience. Journal of Personality and Social Psychology, 52(6), 1258-1265.

Mednick, S. A. (1962). The associative basis of the creative process. Psychological Review, 69(3), 220-232.

Miller, G. F. (2000/2006). A páruálasztó agy. Budapest: Typotex.

Murdock, M., \& GANim, R. (1993). Creativity and humor: Integration and incongruity. Journal of Creative Behavior, 27(1), 57-70.

O'Quin, K., \& Derks, P. (1997). Humor and creativity: A review of the empirical literature. In M. A. Runco (Ed.), The creativity handbook (Vol. 1, 227-256). Cresskill, NJ: Hampton Press.

O’Quin, K., \& Derks, P. (2011). Humor and creativity. In M. A. Runco, \& S. R. Pritcker (Eds.), Encyclopedia of creativity (Vol. 1, 628-636), Second ed., Amsterdam: Elsevier.

Rouff, L. L. (1975). Creativity and sense of humor. Psychological Reports, 37(3), 1022.

SChiller, P. (1938). A configural theory of puzzles of jokes. Journal of General Psychology, 18(2), 217-234.

Sitton, S. C., \& Pierce, E. R. (2004). Synesthesia, creativity and puns. Psychological Reports, 95(2), 577-580.

Smith, E. E., \& White, H. C. (1965). Wit, creativity, and sarcasm. Journal of Applied Psychology, 49(2), 131-134.

Sneed, C. D., McCrae, R. R., \& Funder, D. C. (1998). Lay conceptions of the Five-Factor Model and its indications. Personality and Social Psychology Bulletin, 24(2), 115-126.

Sternberg, R. J., \& Lubart, T. I. (1999). The concept of creativity: Prospects and paradigms. In R. J. SternberG (Ed.), Handbook of Creativity (3-15). Cambridge: Cambridge University Press.

Thorson, J. A., \& Powell, F. C. (1993a). Development and validation of a multidimensional sense of humor scale. Journal of Clinical Psychology, 49(1), 13-23.

Thorson, J. A., \& Powell, F. C. (1993b). Sense of humor and dimension of personality. Journal of Clinical Psychology, 49(6), 799-809.

TISLJÁR R. (2011). A humor szerepe és szerveződése a társas kapcsolatokban - Evolúciós modellek tesztelése. PhD-értekezés. Pécs: PTE BTK. Letöltve: 2013. március 13-án: pszichologia.pte.hu/files/tiny-ince/doctori/D-2011.pdf.

Treadwell, Y. (1970). Humor and creativity. Psychological Reports, 26(1), 55-58.

Turner, R. G. (1980). The wit: A personality analysis. Journal of Personality, 44(3), 307-310. 
Urban, K. K. (2004). Assessing creativity: The Test for Creative Thinking - Drawing Production (TCT-DP) - The concept, application, evaluation, and international studies. Psychology Science, 46(3), 387-397.

Urban, K. K., \& Jellen, H. G. (1996). Test for Creative Thinking - Drawing Production (TCT$D P)$. Lisse: Swets and Zeitlinger.

WiCKER, F. W. (1985). A rhetorical look at humor as creativity. The Journal of Creative Behavior, 19(3), 175-184.

WyCOFf, E. \& PrYor, B. (2003). Cognitive processing, creativity, apprehension, and the humorous personality, North American Journal of Psychology, 5, 31-44.

ZÉTÉNYI T. (1989). A kreativitás-tesztek tesztkönyve. Munkalélektani Koordinációs Tanács Módszertani sorozat 22. kötet. Budapest: Munkaügyi Kutatóintézet.

ZIV, A. (1976). Facilitating effects of humor on creativity. Journal of Educational Psychology, 68(3), 318-322.

ZIV, A. (1989). Using humor to develop creative thinking. In P. E. McGHEE (Ed.), Humor and Children's Development - A Guide to Practical Applications (99-116). Binghamton, NY.: The Haworth Press.

\title{
INTERRELATIONS AMONG HUMOR STYLES AND DIFFERENT ASPECTS OF CREATIVITY
}

\author{
SÉRA, LÁSZLÓ - BODA-UJLAKY, JUDIT - GYEBNÁR, VIKTÓRIA
}

Sense of humor, humor appreciation and humor production are creative features of the personality, with significant individual differences, but the relation between humor production and creativity is not yet clear. In our study $(n=133)$ different self-report and behavioral measures of humor production, humor styles and creativity were administered. Gender differences were not found either on creativity, or on humor scales. Our results suggest a relatively weak, but positive correlation between humor production and creativity, and humor styles that altogether point to the common origin but the different characteristics of the two processes.

Key words: $\quad$ humor, creativity, humor production, humor styles 